\title{
Development and use of state-and-transition models for rangelands
}

\author{
BRANDON T. BESTELMEYER ${ }^{1}$, JOEL R. BROWN ${ }^{2}$, KRIS M. HAVSTAD ${ }^{3}$, ROBERT ALEXANDER ${ }^{4}$, GEORGE \\ CHAVEZ ${ }^{5}$, AND JEFFREY E. HERRICK ${ }^{6}$
}

\begin{abstract}
${ }^{I}$ Ecologist, USDA-ARS, Jornada Experimental Range, New Mexico State University, Las Cruces, N.M. 88003, ${ }^{2}$ Cooperating Research Scientist USDANRCS, Jornada Experimental Range, New Mexico State University, Las Cruces, N.M. 88003, ${ }^{3}$ Supervisory Scientist, USDA-ARS, Jornada Experimental Range, New Mexico State University, Las Cruces, N.M. 88003, ${ }^{4}$ State Range Specialist, Bureau of Land Management, 1474 Rodeo Rd., Santa Fe, N.M. 87502, ${ }^{5}$ State Rangeland Management Specialist, USDA Natural Resources Conservation Service, 6200 Jefferson, Albuquerque, N.M. 87109. ${ }^{6}$ Soil Scientist, USDA-ARS, Jornada Experimental Range, New Mexico State University, Las Cruces, N.M. 88003
\end{abstract}

\begin{abstract}
State-and-transition models have received a great deal of attention since the introduction of the concept to range management in 1989. Nonetheless, only recently have sets of state-and-transition models been produced that can be used by agency personnel and private citizens, and there is little guidance available for developing and interpreting models. Based upon our experiences developing models for the state of New Mexico, we address the following questions: 1) how is information assembled to create site-specific models for entire regions, 2) what ecological issues should be considered in model development and classification, and 3) how should models be used? We review the general structure of state-and-transition models, emphasizing the distinction between changes among communities within states (pathways) that are reversible with changes in climate and "facilitating practices" (e.g. grazing management), and changes among states (transitions) that are reversible only with "accelerating practices" such as seeding, shrub control, or the recovery of soil stability and historical hydrologic function. Both pathways and transitions occur, so these models are complementary. Ecological sites and the climatically-defined regions within which they occur (land resource units) serve as a framework for developing and selecting models. We illustrate the importance of clearly delineating ecological sites to produce models and describe how we have dealt with poorly-delineated sites. Producing specific models requires an understanding of the multiple ecological mechanisms underlying transitions. We show how models can represent and distinguish alternative and complementary hypotheses for transitions. Although there may be several mechanisms underlying transitions, they tend to fall within discrete categories based upon a few, fundamental ecological processes and their relation-
\end{abstract}

We thank several agencies, institutions and individuals who contributed data, knowledge, and criticisms that are represented in this manuscript. From the BLM, Phil Smith, Lane Hauser, Rusty Stovall, Mike Ramirez, Susan Britt, and John Spain; from the NRCS, David Trujillo, Gene Adkins, Garth Grizzle, Darrel Reasner, Tim Henry, Frank Corn, Bill Schwebke, Arlene Tugel, and Pat Shaver; from the U. S. Forest Service, Wayne Robbie and Ralph Pope, from USDA-ARS, Bob Gibbens, from New Mexico State University, Gary Donart and Barbara Nolen; and private citizens, Jim Powell and Lee Gile. Alfonso Serna-Perez and Isaac Reyes-Vera translated the abstract. We thank Sam Fuhlendorf, George Peacock, Nathan Sayre, Mark Westoby, 2 anonymous reviewers, and especially Mitch McClaran for many valuable suggestions. That should not imply that these individuals agree with all that we have written, however.

Manuscript accepted 21 May 02. ships can be readily understood. A knowledge of mechanisms is closely related to the use of ecological indicators to anticipate transitions. We conclude that models should include 1) reference values for quantitative indicators, 2) lists of key indicators and descriptions of changes in them that suggest an approach to a transition, and 3) a rigorous documentation of the theory and assumptions (and their alternatives) underlying the structure of each model.

Key Words: community stability, ecological sites, ecosystem health, indicators, New Mexico, vegetation dynamics

\section{Resumen}

Los modelos del tipo de estado y transición han recibido mucha atención desde su introducción en 1989. Sin embargo hasta hace poco tiempo se cuento con diferentes modelos de 'estado y transición' que pueden ser usados por agencias gubernamentales y particulares. Existen pocos lineamientos disponibles para su desarrollo e interpretación. Basados en nuestra experiencia en el desarrrollo de estos modelos para el estado de Nuevo México, hacemos las siguentes preguntas: 1) i como debe ensamblarse la información para crear modelos para sitios específicos en grandes regiones? 2) i cuales aspectos ecológicos deben ser considerados en el desarollo del modelo y su clasificación? y 3) i como deben usarse estos modelos ? Revisamos la estructura general de los modelos de 'estado y transición' enfatizando los cambios entre comunidades vegetales dentro de estados que son reversibles con los cambios en el clima y practicas facilitadoras (i.e. manejo de pastizales). Asi como cambios entre estados (transiciones) que son reversibles solamente mediante practicas aceleradoras como la resiembra, control de arbustos, y recuperación de la estabilidad y función hidrológica del suelo. las regiones climáticamente definidas (unidades de recursos terrestres) y los sitios ecológicos dentro de ellos sirven como estructura para el desarollo y selección de los modelos. También, ilustramos la importancia de delinear claramente los sitios ecológicos para producir los modelos y describir como hemos resuelto el problema de los sitios pobremente delineados. Para producir modelos específicos se requiere la comprensión de los mecanismos ecologicos que determinan las transiciones. Adicionalmente, mostramos como los modelos pueden representar y distinguir hipotesis alter- 
nativas y/o complementarias para explicar las transiciones. Aun cuando puede haber varios mecanismos para explicar transiciones, estos se consideran dentro de categorias discretas basadas en unos pocos procesos ecologicos fundamentales y sus relaciones pueden ser facilmente comprendidas. El conocimiento de los mecanismos esta estrechamente ligado al uso de indicadores ecológicos para anticipar las transiciones. Concluimos que los modelos deben de incluir 1) valores de referencia para indicadores cuantitativos, 2) lista de indicadores clave y descripción de sus cambios que sugieran una aproximación a una transición, y 3) una documentación rigurosa de las teorias y asunciones (y sus alternativas) que dan base a la estructura de cada modelo.

Ecological theory provides a basis for land management. An understanding of the processes inferred to cause population or community patterns determines how managers should respond to patterns. A prime example is the succession-retrogression (or range condition) model of Dyksterhuis (1949) that is based on the successional theory of Clements (1916) and the edaphic polyclimax concept of Tansley (1935). This model emphasized the return of disturbed communities to a competitively-determined climax state and has been a guiding principle in range management (Westoby 1980). Upon recognizing an undesirable trend in plant community composition, managers could respond by reducing or redistributing grazing pressure and effect a return to desirable conditions. An important reason for the success of this model is that it provided a method to measure and compare land condition against the expectations of the model (i.e., the similarity index), thus providing a concrete link between theoretical expectations and management response.

Rangeland managers have long recognized that semiarid grasslands can transform into shrub-dominated states that cannot be returned to grassland through grazing management (Laycock 1991), contrary to applications of the succession-retrogression model. Assuming that a single, competition-defined equilibrium plant community should exist for each site, alternative states, and the rangelands in which they occur, have been referred to as "non-equilibrial" (following Wiens 1984). In fact, these alternative states may be highly equilibrial (e.g., Muller 1940) after the transition, so these systems are better termed multi-equilibrial. The increasing emphasis on processes other than competi- tion in determining community patterns (Kingsland 1985), paved the way for Westoby et al. (1989, Westoby 1980) to propose a revised framework for range management. The state-and-transition model formally acknowledged the multiequilibrial nature of many rangeland ecosystems and the rapid and unanticipated shifts among these equilibria. Furthermore, Westoby et al. (1989) focused attention on the multiple mechanisms underlying alternative equilibria and emphasized an "opportunistic" style of management in which strategies vary depending upon which mechanisms are important. The state-and-transition concept provides a means for anticipating departures from the monoclimax model and incorporating this understanding into management plans. Consequently, this concept is being widely espoused within the range science community of the United States (Society for Range Management 1995, USDA NRCS 1997). For agencies such as the Natural Resources Conservation Service (NRCS) and Bureau of Land Management (BLM), state-and-transition models promise to improve assessment, monitoring, and management in many semiarid rangelands.

Twelve years after the seminal publication of the state-and-transition concept, however, few applications of the concept exist that can be used by land managers. This is not to say that there has not been a great deal of work on the concept. Researchers have provided refinements to underlying ideas (Laycock 1991, Freidel 1991, Rodriguez-Iglesias and Kothmann 1997, Reitkerk and van de Koppel 1997), technological advances in the production and quantification of models (Wiegand and Milton 1996, Allen-Diaz and Bartolome 1998, Plant et al. 1999), and some site-specific conceptual models (e.g., Archer et al. 1988, Ash et al. 1994, George et al. 1992). There have been few attempts, however, to develop sets of sitespecific models based upon existing information that can be applied by land managers in a systematic way over broad areas. Here, we relay some of the insights gained during the production of state-andtransition models for rangelands in the state of New Mexico, USA.

Like other western states, New Mexico is dominated by semiarid rangelands and the limitations of the monoclimax model are very apparent in many of these ecosystems. State-and-transition models have the potential to provide a framework for organizing complex sets of ideas about the multiple, interactive processes driving ecosystem change and the roles that management can play in directing these processes. The details of these models can draw upon a wealth of recent conceptual and technological advances in community and landscape ecology, including the relationships between positive feedback mechanisms and threshold changes in processes such as erosion (Davenport et al. 1998), the dependency of threshold changes on processes operating on different scales of space and time (Scheffer et al. 2001), and understanding the linkages among processes using ground-based and remotely-sensed patterns (Rango et al. in press). Implementing these advances to improve on-site management of rangelands, however, presents substantial challenges, among them: 1) how do we draw together the detailed information required to create site-specific models that are applicable across entire regions, 2) what ecological issues need to be considered in developing and classifying sets of models, and 3) given the models that can be produced, what do we want to use them for and how should they be used? In addressing these general questions about stateand-transition model development, we draw on examples from state-and-transitions models developed in a range of landscapes in New Mexico.

\section{What is a state-and-transition model?}

The idea that rangeland vegetation exhibits multiple states, and transitions among them, has been referred to generally as the state-and-transition model. These concepts have been adequately reviewed elsewhere (Laycock 1991, Brown 1994, Rodriguez-Iglesias and Kothmann 1997, Stringham et al. 2001). To be operational, however, specific state-and-transition models must be created that describe the details of vegetation dynamics for particular land areas. The graphical and conceptual format provided by Westoby et al. (1989), with modifications most recently summarized by Stringham et al. (2001; Fig. 1), illustrate several key elements that are communicated in these conceptual models. The model format presented here is based upon that currently used and presented by the NRCS.

As in vegetation mapping (Grossman et al. 1998), the most basic unit is the plant community. This is the relatively homogeneous assemblage of plants that occurs at a particular point in space and time, and can be defined at a scale relevant to a land manager (e.g., 0.1-10 ha). In the models for New Mexico, plant communities are 


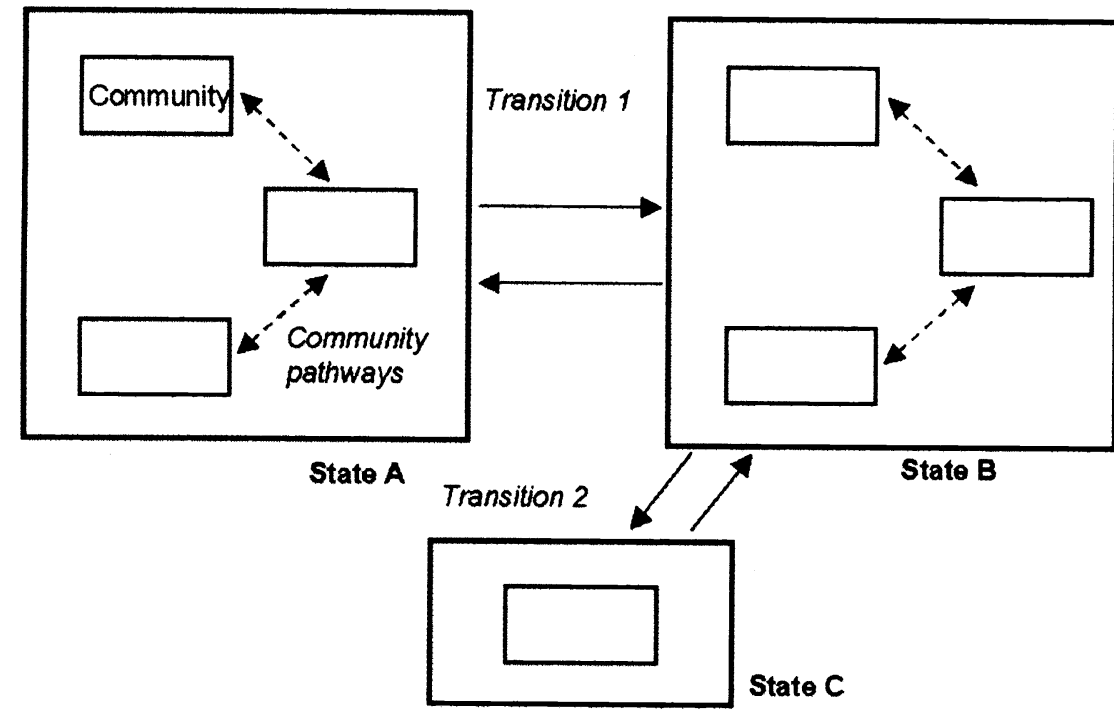

Fig. 1. The general structure of state-and-transition models after Stringham et al. (2001). The small boxes represent individual plant communities and the dashed arrows between them represent community pathways along which shifts among communities occur. These shifts are reversible through facilitating practices and fluctuations in climate. The large boxes containing communities are states that are distinguished by differences in structure and the rates of ecological processes (such as erosion). The transitions among states (solid arrows) are reversible only through accelerating practices (e.g. seeding, shrub control, or addition of soil) that can be applied at relatively great financial expense.

often defined by dominant species, or species that indicate the operation of particular processes (e.g., an encroaching shrub species, whether or not it is now dominant). Descriptions of plant communities may also contain information on soil conditions that indicate processes (e.g., the cover of physical, chemical or cryptogamic crusts). It is important to identify the range of plant communities in a land area because these are the observable and measurable links to the processes embodied in the remaining components of the model. Plant community identity at a location may vary in time and the arrows between communities indicate changes (or "community pathways") among them. These shifts in plant composition, as opposed to those referred to as "transitions" (see below), may be caused by climate or land use but are reversible by simply altering the intensity or direction of the factors that caused the change in composition (e.g., practices that reduce grazing pressure or increases in rainfall after a drought). The "facilitating practices" as defined by the NRCS (USDA NRCS 1997) would produce responses along community pathways. Thus, the succession-retrogression model operates along community pathways and is embedded within the stateand-transition model.

Communities are aggregated into states (Fig. 1) that are distinguished from other states by relatively large differences in plant functional groups and ecosystem processes and, consequently, in vegetation structure, biodiversity, and management requirements. For example, a grassland, whether it is dominated by one grass species or another, may provide sufficient cover to prevent rain-drop compaction of the soil surface and to intercept water and nutrients before they are lost from the system. In doing so, dominance by either grass species can sustain the soil conditions required by the other, and replacements along community pathways may occur within the state. Once grass cover has been reduced below a critical amount (Davenport et al. 1998), or a shrub species invades that leads to grass loss (Brown and Archer 1999), infiltration is reduced and erosion accelerates, a change in soil conditions occurs, and the system crosses into a new state. This new state is characterized by a distinct set of plant communities and a distinct range of values for ecosystem attributes.

The shift between states is referred to as a "transition". Unlike community pathways, transitions are not reversible by simply altering the intensity or direction of the factors that produced the change (c.f. the "amplitude" of Westman 1978) and instead require the application of distinct factors such as the addition of seeds, the removal of shrubs, or the addition of topsoil. These "accelerating practices" as defined by the NRCS (USDA NRCS
1997) are often expensive to apply. Generally, transitions among ecosystem states are thought to be caused by a combination of external and internal, positive feedback mechanisms that alter constraints on the presence or abundance of particular plant species (e.g., Schlesinger et al. 1990; Fig. 2). Three general classes of constraints can be recognized: 1) the dispersal of propagules to a site and subsequent reproduction, 2) "neighbor" constraints, including the effects of competitors, predators, or parasites, as well as the tendency of certain life-forms to facilitate fire disturbance, and 3) "site" constraints, including soil properties, hydrology, and climate. Transitions occur when 1 or more constraints are altered by external factors and this change catalyzes changes in positive feedbacks that produce relatively important shifts in vegetation structure and soil properties. Multiple external factors can be affected by singular processes, such as livestock grazing (e.g., by introducing shrub propagules and decreasing competition with them). Furthermore, changes in one class of constraints may reinforce changes in other constraints, such that several positive feedback mechanisms operate together (c.f. Archer 1989).

For example, heavy, continuous livestock grazing may initiate changes to shrub colonization ability by providing a dispersal pathway for seeds and reducing competition and fire disturbance by removing grasses. Reduced competition and fire disturbance may permit shrub establishment and growth. The presence of adult shrubs 1) increases shrub seed availability through reproduction and facilitates the dispersal of additional seeds to the site by attracting birds, 2) increases competition with grasses and limits grass reestablishment, and 3) increases erosion rates and nutrient loss from shrub-interspaces by reducing grass basal cover. Alternatively, prolonged and severe drought or mechanical disturbance (e.g., off-road vehicles) might catalyze a similar sequence of events if shrub seeds were already present.

Thus, different states can be viewed as separating positive feedbacks between different kinds of plants and different ecosystem processes. For example, by retaining soil nutrients and high infiltration capacity over relatively homogeneous areas (Ludwig et al. 1994), or by promoting fire (McPherson 1995), grasslands sustain themselves. By promoting intershrub erosion and heterogeneous nutrient distributions, or by outcompeting grasses for water, shrublands promote shrublands (Schlesinger et al. 1990). Once competi- 


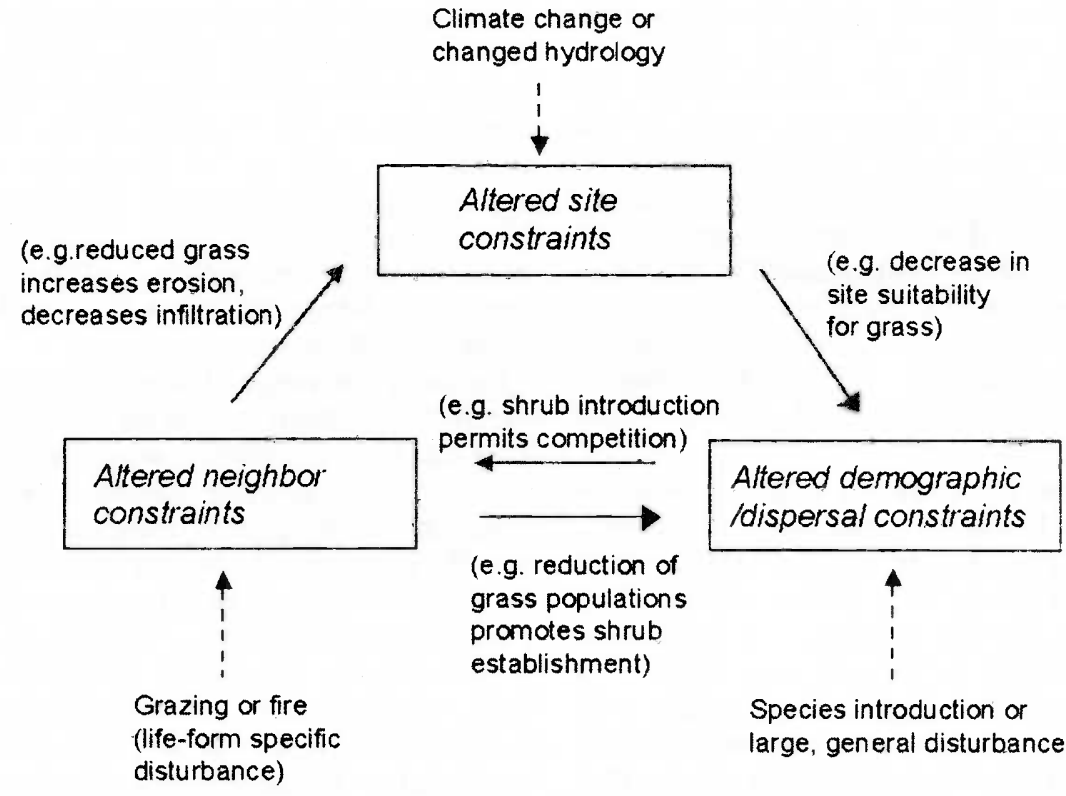

Fig. 2. The relationships among the classes of constraints that are altered to produce an ecosystem transition, and the internal and external processes that affect these constraints. External processes (dashed arrows) act as environmental triggers that set in motion positive feedbacks represented by the internal processes (solid arrows). Processes affecting particular constraints interact with one another such that multiple mechanisms produce and maintain transitions. See text.

tive dominants are introduced, species are lost, or soil properties are significantly altered, transitions can be difficult and expensive to reverse. An understanding of the constraints to ecosystem change, and the relationships between the external and internal mechanisms affecting them, suggest strategies for predicting and avoiding transitions and devising restoration strategies (Whisenant 1999). Although the causes of individual transitions in models are varied, the mechanisms involved fall into readily-understood classes (Fig. 2) that are common to all models.

State-and-transition models, then, represent postulates about the causes of both ephemeral and persistent changes in vegetation at a site and should offer testable predictions. Moreover, the models provide a logical framework in which assumptions and concepts about how rangelands work must be specified. This can add clarity to our ideas about rangelands, and often reveals how little we really know about them.

\section{Model classification using ecological sites}

Before a model can be created and tested, it is critical to define the extent over which a single model will apply. For arid rangelands in the United States, this extent is currently defined by the ecological sites of the NRCS (USDA NRCS 1997).
Historically, ecological sites (previously called range sites) were based solely on similarities in the composition and productivity of dominant, climax vegetation (Shiflet 1975). Ideally, ecological sites are a classification of land types based on dif- ferences in important environmental factors, including soil properties, slope, and landscape position (e.g., in an upland or swale). These differences correspond to differences in the structure of plant communities, and with respect to state-andtransition models, plant community dynamics in the face of natural and human-caused disturbance (Society for Range Management 1995). Ecological sites are mapped by grouping soil mapping units on which plant communities are assumed to behave similarly. Ecological sites occur together in a landscape as a mosaic determined by patterns of geomorphology (Fig. 3c). Like other vegetation classification systems, ecological sites are nested within a hierarchy of climaticallydefined regions (Fig 3a, 3b). The extent of a particular ecological site is bounded within an area of similar geology and cli mate, the land resource unit of the NRCS or ecoregion of the U.S. Forest Service, beyond which analogous ecological sites may exist. Thus, a particular state-andtransition model is intended to apply to one ecological site that can be found within only one land resource unit.

The definition of ecological sites (Creque et al. 1999) and land resource units is often arbitrary. Given the importance of soils and climate for the nature of vegetation dynamics, the validity of any state-and-transition model will depend upon the amount of variation in important

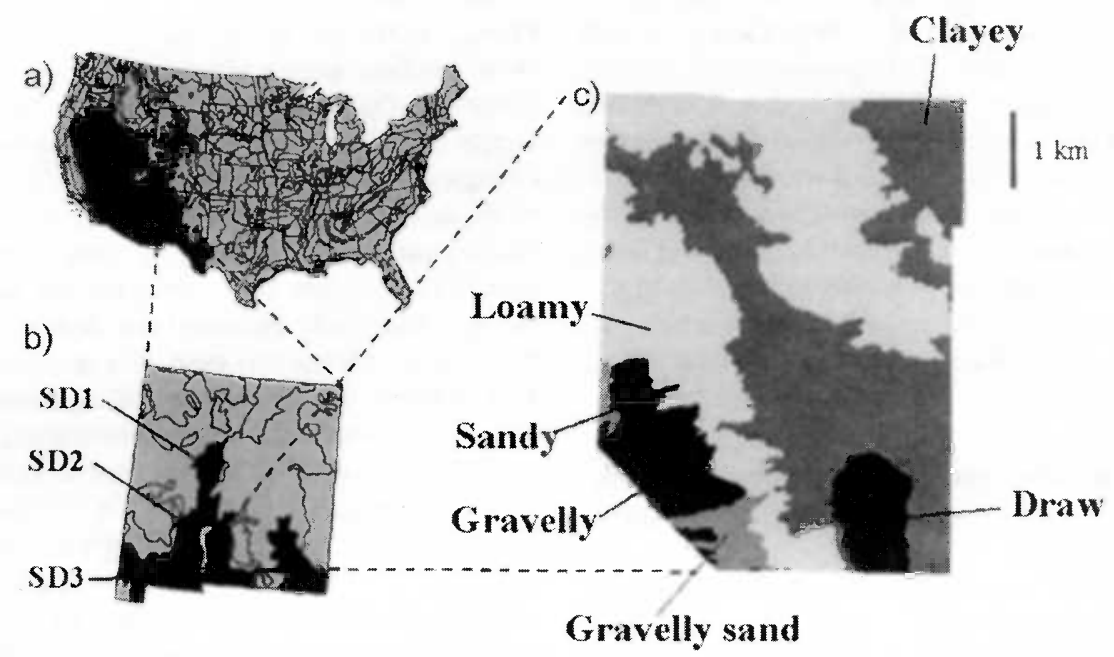

Fig. 3. The land-unit classification framework within which state-and-transition models are being developed by the Natural Resources Conservation Service. a) the Land Resource Region scale, highlighting the Western Range and Irrigated Region within which land resource units are embedded, b) the Major Land Resource Area scale: Southern Desertic Basins, Plains, and Mountains within New Mexico. Land resource units (SD-1, SD-2, SD-3) are noted with arrows. A unique set of ecological sites and state-and-transition models are common to each subresource area. c) a map of ecological sites for part of the Jornada Experimental Range based on groups of related soil series (draft soil map courtesy of Dr. Lee Gile and Barbara Nolen, the Desert Soils Project). 
soil properties and climate within ecological sites and land resource units, respectively. If land assigned to ecological sites does not exhibit consistent properties, it may not be clear whether the variation in plant communities observed between 2 areas within the same ecological site is due to a vegetation transition or to static differences in environmental conditions (Friedel et al. 1993). For example, burrograss (Scleropogon brevifolius Phil.) is a mat-forming native perennial grass of the Chihuahuan Desert, is often dominant on loamy or clayey ecological sites, and is relatively unpalatable to livestock. Thus, dominance by burrograss is often assumed to be related to management practices and drought. While this may be the case on Stellar clay loam soils that were formerly dominated by tobosa (Pleuraphis mutica Buckl.), burrograss may have been historically dominant on Reagan clay loam soils (Leland Gile, personal communication). Reagan soils are highly calcareous at shallow depths relative to Stellar (see Gile and Grossman 1997) and are less pervious to water than are Stellar soils in a similar landscape position (Herbel and Gibbens 1989). Although Stellar, Reagan, and other soils have been grouped within the same ecological site, these soils clearly exhibit distinct properties and have probably always harbored distinct communities.

To distinguish management-produced from natural patterns (especially in the absence of historical data), it will be necessary to rigorously delineate ecological sites (Creque et al. 1999). Doing so will require that we distinguish ecological sites based upon values of soil and climatic variables that correspond to differences in the nature of state-and-transition models. In turn, this necessitates a detailed documentation of the relationships between plant communities and their dynamics to soil series. Such efforts will in many cases lead to reassignments of soils to ecological sites and the creation of new ecological sites.

\section{Building state-and-transition models Defining communities and community pathways}

Once an ecological site has been selected, the first task in creating a state-andtransition model is to define the communities that can occur within that ecological site. A key benchmark is represented by the "historic climax plant community" of the NRCS (USDA NRCS 1997). This community represents the composition of plants that is known or is presumed to have dominated an ecological site prior to the settlement of Europeans, and is high- lighted in the ecological site description. Furthermore, this community is often believed to be the one in which soil resources and native biodiversity is best conserved (but see Belsky 1996). Thus, the state bearing this community (along with related successional stages) is the global management standard of the BLM and the standard is implicit in the activities of other agencies and non-governmental organizations (c.f. USFS 2000, Bureau of Land Management 2001, Strittholt and Boerner 1995).

There are, however, several limitations to the historic climax plant community concept. First, in much of the western United States, the historic climax plant community does not now exist and cannot be reliably estimated from historical records. Thus, historic climax plant communities are sometimes estimated with the hidden assumption that the plants that were most palatable to livestock were the competitive dominants in the historic climax plant community (Westoby 1980). Second, the notion of the competitivelydetermined climax state is explicitly acknowledged in the historic climax plant community, and this is at odds with the multi-equilibrium concept now embraced by agencies (Svejcar and Brown 1991). That is, climaxes may shift, even without human influence, such that a climax is a "moving target" over broad time scales due to climate change (Brown et al. 1997). For example, it is possible that the dominance of black grama (Bouteloua eriopoda (Torr.) Torr.) on sandy soils of southern New Mexico was a consequence of climatic conditions peculiar to the late nineteenth century (Neilson 1986). A regional change in climate may now preclude sufficient sexual reproduction to reestablish black grama as a dominant in many areas, and it is possible that overgrazing and drought have only hastened the demise of this species. Given this case, it is questionable whether the restoration of a productive black grama-dominated community would be a suitable management goal. Third, aggregating soils with distinct inherent properties into ecological sites leads to the development of uniform expectations where they may not be warranted. For example, creosotebush (Larrea tridentata (DC) Cov.) has likely been dominant on erosional fan remnants at the base of Mount Summerford in southern New Mexico since before European settlement (Wondzell et al. 1996). The ecological site in which these soils are now grouped (Bulloch and Neher 1980), however, would lead one to the conclusion that creosotebush had encroached and displaced climax native grasses. Defining appropriate management standards via the state-and-transition (or the succession-retrogression) approach requires that we acknowledge and accept data limitations, take into account the multi-equilibrium nature of plant communities, and develop ecological sites based on a detailed understanding of plant-soil relationships.

Defining the range of alternative communities occurring in several ecological sites can be accomplished using monitoring data, such as those gathered by the Long-Term Ecological Research program, the BLM, the NRCS, private individuals, as well as repeated aerial or terrestrial photography from a variety of sources (e.g., Callaway and Davis 1993, Miller 1999, McClaran et al.). In many cases however, the number of ecological sites monitored or the duration of monitoring is limited. Interviews of rangeland professionals, researchers, and ranchers (Bellamy and Brown 1994) in conjunction with structured, rapid vegetation surveys based on soil maps and associated with soil series determinations can add significantly to the number of communities encountered and provide rigorous associations of communities with soil properties.

A practical limitation of using professional testimony and casual field observations to define communities is that it is often unclear how communities are related in time. The number of communities included within an ecological site may be an artifact of the persistent environmental heterogeneity in space included within an ecological site definition, rather than temporal variability at points in space. When it is suspected that 2 communities do not occur at the same points in space, the creation of a new ecological site may be called for. Alternatively, (or while new ecological sites are developed), we can denote the absence of temporal relationships among communities by having them "float" within the state and not be connected to other communities by community pathways (Fig. 4). In other cases, areas with differing aspect or slope are circumscribed in ecological site definitions, and northern and southern exposures may exhibit distinct species composition and dynamics. Nonetheless, these areas function similarly enough (or are so predictably associated) that they are considered within the same ecological site and state.

\section{Defining states and transitions}

States have been defined based on shifts in plant community structure using multi- 


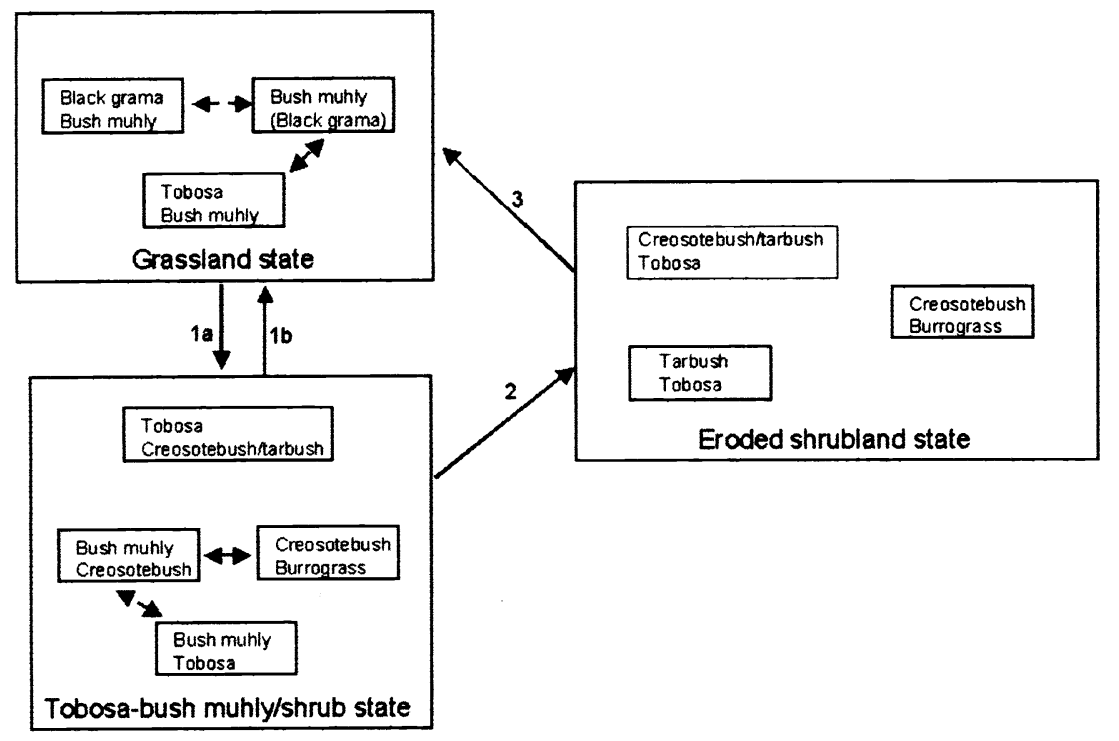

Fig. 4. A draft state-and-transition model for the gravelly loam ecological site within the SD2 land resource unit of southern New Mexico. Transition 1 is caused by grass loss and subsequent shrub invasion, whereas transition 2 is caused by soil degradation. Transition 3 requires shrub removal, grass seeding, and restoration of soil fertility and permeability. The communities within the eroded shrubland state are not connected by arrows, indicating that there is no evidence for replacement among these community types. Instead, these distinct community types seem to reflect variation among soils included within the ecological site, although there is not yet enough information to reliably split soils into separate ecological sites. Black grama, bush muhly (Muhlenbergia porteri Scribn.), tobosa, and burrograss are perennial grasses; burrograss is usually least palatable to cattle. Creosotebush and tarbush (Flourensia cernua D.C.) are shrubs. and conditions that lead to dominance by other species (Neilson 1986). Changed climate or further soil degradation may lead to black grama extinction and dominance by bunchgrasses that are able to reproduce by seed (transition 2). The transition to a shrub-invaded state is catalyzed by either the introduction of mesquite propagules into grassland (Brown and Archer 1987) or by the competitive release of existing mesquite seedlings through the reduction of grass cover (Van Auken and Bush 1997), fire frequency (Wright et al. 1976), or shrub seedling herbivores (Weltzin et al. 1997; transition 3a). Alternatively, propagule introduction might occur after or concurrent with a change in climate or soil degradation (Hennessy et al. 1983; transitions $4 \mathrm{a}, 5 \mathrm{a}$ ). Initiated by these external triggers, the loss of black grama may be caused by a shift in positive feedbacks involving competition, erosion, and physical and chemical changes to soils (Schlesinger et al. 1990, Herrick et al. 2002) due to the presence of shrubs (transition 6). Shrubs would need to be removed to return to the black gramadominated (transition $3 b$ ) or limited $(4 b)$ state. Shrub expansion may need to be controlled in order to remain in the shrubinvaded state, although coexistence variate analyses of long-term data sets (Allen-Diaz and Bartolome 1998). While this approach is objective and potentially repeatable, it does not consider the processes or mechanisms involved in community changes. Furthermore, most applications do not demonstrate that plant communities have entered a new domain of variability (e.g., Friedel 1991) that indicates a fundamental change in the functioning of the ecosystem (Whisenant 1999). Thus, it is unclear whether changes in plant composition can be reversed through facilitating or accelerating practices (Stringham et al. 2001).

Given these uncertainties and the paucity of long-term data supporting the existence of multiple domains of variability, states and transitions can be constructed based upon postulates of vegetation change in combination with empirical observations of community structure and environmental conditions. For example, a number of explanations for the well-documented loss of black grama and increase in honey mesquite (Prosopis glandulosa Torr.) may pertain to Sandy ecological sites in south-central New Mexico (Fig. 5). The transition to a black grama-limited state (transition 1a) represents the shift between climatic or soil fertility conditions conducive to black grama dominance

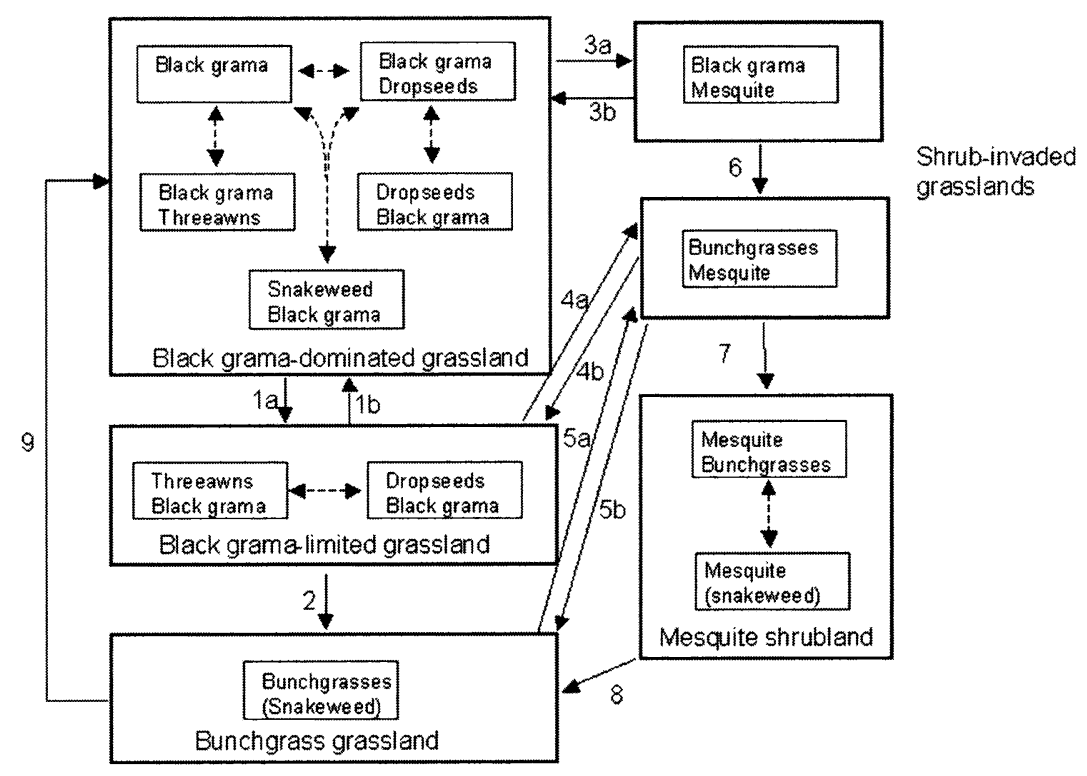

Fig. 5. A state-and-transition model for the sandy ecological site within the SD-2 land resource unit of southern New Mexico. Black grama, dropseeds (Sporobolus R. Br. spp.) threeawns (Aristida L. spp. ) are perennial grasses. Black grama is palatable to cattle for a longer duration than the other species and comparatively sensitive to grazing pressure. Snakeweed (Xanthocephalum Willd. spp.) is a subshrub that tends to invade with reductions in grasses or with adequate winter-spring precipitation. Mesquite is a large shrub that tends to invade intact or degraded grasslands, promote the loss of grasses in intershrub spaces, and concentrate resources beneath its canopy. 
between bunchgrasses and mesquite without shrub control may persist for long periods if soil degradation is not aggravated by environmental stress. If grazing, drought, or shrub encroachment continue to reduce the remaining grass cover, erosion and/or increases in rodent and rabbit densities (Campbell 1929) eventually lead to the formation of stable coppice dunes with the loss of most grasses (transition 7). At this point, natural reestablishment may not be possible for most grass species. In principle, the mechanical restoration and stabilization of topsoil and addition of soil nutrients and microorganisms following shrub removal could be used to initiate grassland recovery (transitions 8, 9)

In this example, the definition of each of the states depend critically on our notions of the processes driving vegetation change and our responses to them. For example, the shrub-invaded state may be defined by either the presence of shrub seedlings, or the presence of shrubs seedlings in the context of particular stresses or changes to disturbance regimes. If the presence of shrubs with grasses for long periods accelerates grass loss, a shrub-invaded state may be supported only by intensive accelerating practices. Alternatively, this situation might simply be considered as an early stage of a shrub-dominated state if shrub control was not implemented. In addition, we proposed that some communities (e.g. the dropseed/black grama community) occur in 2 distinct states. This denotes that communities with similar vegetation structure may have very different responses to management due to differences in climate or soil properties between the states. States are human constructs that represent our understanding of and relationships with rangelands.

By definition, the recognition of states and transitions also depends on temporal scale (Friedel 1997) and, thus, our ideas of stability and equilibrium. In many cases, such as when grasslands are converted to mesquite dunes, the difference between community pathways and transitions between states is clear. In other cases, it is not. For example, bottomland/draw system degradation in the New Mexico Plateaus and Mesas land resource unit may exhibit a cyclic sequence of "states" over a period of 50-100 years without the use of accelerating practices (G. Adkins, NRCS, personal communication). Erosion and channelization due to reduced grass cover leads to decreased soil moisture availability and a transition from giant sacaton (Sporobolus wrightii Munro) or alkali sacaton ( $S$. airoides (Torr.) Torr.) grass- lands to blue grama (Bouteloua gracilis (H.B.K.) Lag. ex Steud. Hitchcock) grasslands characteristic of upland sites. Subsequently, agradation of soil into channels will lead to a return of flooding cycles, and bottomland grasslands may reestablish with improved grazing management. Ecological sites and regions may differ in the degree to which hydrology, climate, or other physical features create stability over particular time scales, blurring the distinction between pathways and transitions among "stable" states (Fuhlendorf et al. 2001). Nonetheless, when intensive accelerating practices (such as gully stabilization) can be used to hasten relatively slow natural processes or recovery, the recognition of distinct states is useful. Stability must be defined relative to a time scale, so it is important to consider how the scale over which natural recovery is observed matches management timeframes when defining states.

The relationship between states, transitions, and ecological sites

When a transition involves changes in soil structure, the resulting vegetation/soil change may be so permanent that it is considered a new ecological site rather than a state. The NRCS National Range and Pasture Handbook states "Severe physical deterioration can permanently alter the potential of an ecological site to support the original community" (USDA NRCS 1997). This may apply when soils are truncated to the point where an eroded phase is recognized in soil classification. For example, the loss of sandy surface horizons on some sandy loam soils may expose clay-rich strata that no longer support the germination or survival of formerly dominant species (Gile and Grossman 1997). The point at which a new ecological site should be recognized, however, depends on the fuzzy distinction between changes that are "persistent" (Stringham et al. 2001) without the use of accelerating practices (i.e., a transition) and "permanent" change. We should also be aware of the consequences of losing track of the occurrence of historic communities at a site-do we want to maintain documentation that a particular area used to be grassland but is now shrubland? The amount of financial resources required to apply accelerating practices to reverse a transition may be a suitable criterion for deciding when to create a new ecological site. Constraints due to biotic interactions, for example, are often less expensive to overcome than abiotic limitations (Whisenant 1999). We suggest, however, that the concept of "state" may be sufficient to describe persistent changes due to various causes and creating new ecological sites would be an unnecessary semantic complication.

Unexpected transitions among states (or sites) may depend upon the transitions occurring in adjacent sites. On the loamy soils of the Jornada Experimental Range, for example, wind erosion of degraded sandy soils to the west of loamy soils has resulted in the accumulation of sand on the loamy soils (C. Monger, personal communication). These patches support black grama grass that is absent on the unaltered soils. Herbel et al. (1972) speculate that the increased abundance of tobosa relative to black grama and other grasses on lower piedmont clayey sites is due to the increased water run-on from degraded gravelly sites occurring upslope. It is important to recognize that some transitions may have extrinsic causes that depend upon landscape context rather than local management.

\section{Patterns in sets of state-and-transi- tion models}

Given the issues and approaches discussed in the preceding sections, what generalizations can be drawn from the models we have created? To date, we have produced about 60 draft or completed models spanning 4 land resource units in southwestern-southcentral New Mexico. These land resource units intergrade with one another, and differ in subtle ways based on moisture and temperature (Table 1). Some of the patterns that we have observed can be compared among land resource units using models from a set of common ecological site types representing a gradient of landscape position and soil properties. In general, we see that more states per ecological site were generated for thermic, aridic soils of SD-2 (i.e., the southern desert unit 2 land resource unit) than for the soils experiencing more ustic and/or mesic regimes in higher elevation or more northerly land resource units. This may be due to 1 or 2 non-exclusive causes: 1) more ecological sites within relatively warm and arid regions are subject to a variety of processes that lead to several states (e.g. erosion plus shrub invasion or expansion; Table 1) and 2) land-use professionals recognize more states in SD-2 because of the relatively extensive research conducted there. Another feature apparent in the groups of models is the wide range in the number of states. Some models (e.g. SD-1 Hills) have only one state, implying that the site is resilient with facilitating practices alone and that 
Table 1. The number of states and key constraints defining the states for 7 common classes of ecological sites within 4 Land Resource Units (e.g., SD-2) in southern New Mexico. The Land Resource Units chosen differ in mean annual precipitation (MAP) and soil moisture regime (MR) and/or mean annual temperature (MAT) and soil temperature regime (TR) but all occur within south-central to southwestern New Mexico. The number of states and key constraints are based on published literature and interviews with rangeland professionals. These models may be viewed at the NRCS New Mexico website: http://www.nm.nrcs.usda.gov/techserv/fotg/Section2/esd.htm

\begin{tabular}{|c|c|c|c|c|c|c|c|c|}
\hline \multirow[b]{2}{*}{$\overline{\text { Ecological Site }}$} & \multicolumn{2}{|c|}{$\begin{array}{l}\text { MLRA 42, SD-2* } \\
\text { Latitude: } 31^{\circ} 19^{\prime}-34^{\circ} 24^{\prime} \\
\text { Longitude: } 105^{\circ} 50^{\prime}-109^{\circ} 02^{\prime} \\
\text { 8-10" MAP; } 15.5^{\circ} \mathrm{C} \text { MAT } \\
\text { MR: Aridic } \\
\text { TR: Thermic }\end{array}$} & \multicolumn{2}{|c|}{$\begin{array}{l}\text { MLRA 42, SD-1* } \\
\text { Latitude: } 33^{\circ} 27^{\prime}-35^{\circ} 21^{\prime} \\
\text { Longitude: } 106^{\circ} 25^{\prime}-107^{\circ} 07^{\prime} \\
8 \text {-11" MAP; } 13.3^{\circ} \mathrm{C} \text { MAT } \\
\text { MR: Ustic-Aridic } \\
\text { TR: Thermic-mesic }\end{array}$} & \multicolumn{2}{|c|}{$\begin{array}{l}\text { MLRA 42, SD-4* } \\
\text { Latitude: } 31^{\circ} 40^{\prime}-32^{\circ} 30^{\prime} \\
\text { Longitude: } 105^{\circ} 39^{\prime}-105^{\circ} 55^{\prime} \\
\text { 12-14" MAP; } 15^{\circ} \mathrm{C} \text { MAT } \\
\text { MR: Ustic-Aridic } \\
\text { TR: Thermic }\end{array}$} & \multicolumn{2}{|c|}{$\begin{array}{l}\text { MLRA 36, WP-3* } \\
\text { Latitude: } 32^{\circ} 22^{\prime}-34^{\circ} 35^{\prime} \\
\text { Longitude: } 106^{\circ} 58^{\prime}-109^{\circ} 02^{\prime} \\
\text { 12-16" MAP; } 13.3^{\circ} \mathrm{C} \text { MAT } \\
\text { MR: Ustic-Aridic } \\
\text { TR: Mesic }\end{array}$} \\
\hline & $\begin{array}{l}\text { \# of } \\
\text { states }\end{array}$ & Key constraints & $\begin{array}{l}\text { \# of } \\
\text { states }\end{array}$ & Key constraints & $\begin{array}{l}\text { \# of } \\
\text { states }\end{array}$ & Key constraints & $\begin{array}{l}\text { \# of } \\
\text { states }\end{array}$ & Key constraints \\
\hline Bottomland & 5 & $\begin{array}{l}\text { Gullying } \\
\text { Blocked run-on } \\
\text { Mesquite invasion }\end{array}$ & 3 & $\begin{array}{l}\text { Gullying } \\
\text { Blocked run-on }\end{array}$ & 2 & $\begin{array}{l}\text { Gullying } \\
\text { Blocked run-on }\end{array}$ & 3 & $\begin{array}{l}\text { Gullying } \\
\text { Blocked run-on }\end{array}$ \\
\hline Swale/Draw & 5 & $\begin{array}{l}\text { Gullying } \\
\text { Soil sealing } \\
\text { Blocked run-on } \\
\text { Mesquite invasion }\end{array}$ & 2 & $\begin{array}{l}\text { Gullying } \\
\text { Blocked run-on }\end{array}$ & NA & --- & NA & -- \\
\hline Clayey/Clay upland & 6 & $\begin{array}{l}\text { Soil sealing } \\
\text { Blocked run-on } \\
\text { Shrub invasion } \\
\text { Erosion/soil loss }\end{array}$ & 2 & $\begin{array}{l}\text { Soil sealing } \\
\text { Erosion/soil loss }\end{array}$ & 2 & $\begin{array}{l}\text { Blocked run on } \\
\text { Soil sealing }\end{array}$ & 2 & Gullying \\
\hline Loamy (Draw) & 4 & $\begin{array}{l}\text { Soil fertility loss } \\
\text { Shrub invasion } \\
\text { Erosion/soil loss }\end{array}$ & 4 & $\begin{array}{l}\text { Soil fertility loss } \\
\text { Erosion/soil loss }\end{array}$ & 3 & $\begin{array}{l}\text { Creosotebush invasion } \\
\text { Erosion/soil loss }\end{array}$ & 2 & $\begin{array}{l}\text { Soil fertility loss? } \\
\text { Gullying }\end{array}$ \\
\hline Sandy/Loamy sand & 6 & $\begin{array}{l}\text { Soil fertility loss } \\
\text { Mesquite invasion } \\
\text { Soil-surface instability } \\
\text { Erosion }\end{array}$ & 2 & $\begin{array}{l}\text { Soil fertility loss? } \\
\text { Sand sage expansion }\end{array}$ & 2 & Sand sage ${ }^{3}$ expansion & 3 & Mesquite invasion \\
\hline Gravelly & 3 & $\begin{array}{l}\text { Creosotebush } \\
\text { expansion }^{2} \\
\text { Erosion/soil loss }\end{array}$ & 3 & $\begin{array}{l}\text { Soil fertility loss } \\
\text { Creosotebush } \\
\text { invasion }\end{array}$ & 2 & Creosotebush expansion & 4 & $\begin{array}{l}\text { Erosion/soil loss } \\
\text { Juniper }{ }^{4} \text { invasion }\end{array}$ \\
\hline Hills & 2 & Erosion/soil loss & $1 ?$ & --- & NA & --- & 3 & Juniper invasion \\
\hline Mean number of states $* *$ & 4.8 & & 2.8 & & 2.2 & & 2.8 & \\
\hline
\end{tabular}

the succession-retrogression model adequately describes its dynamics. At a continental level, this may be true of many rangeland communities that are resistant to soil degradation, not dependent on surface hydrologic inputs, or not subject to invasion by competitive species.

Can we generalize about the importance of particular processes in different ecological site types or land resource units? In some cases, we find that the same types of processes are invoked to explain transitions in similar ecological sites: lowland sites such as bottomlands, draws and clayey sites are subject to changes in surface hydrology and surface soil structure and chemistry with respect to infiltration. Changes among states in upland sites such as sandy, gravelly, and hills sites are often subject to erosion and loss of soil fertility. The importance of shrub or tree invasion, on the other hand, seems to depend on the ecological site/land resource unit combination in question, although in some land resource units (e.g. SD-2) it is more important than in others. Overall, we see that a subset of common processes in various combinations explain vegetation dynamics within different ecological sites. This allows us to make some generalizations, while requiring that these generalizations be carefully evaluated for each ecological site and land resource unit.

\section{Using models: proximate variables, indicators, and predicting transitions}

The primary use of state-and-transition models is to depict the circumstances sur- rounding past vegetation changes on ecological sites and to use this information to anticipate and interpret changes in the future. Beyond this general function, identifying the operation of processes underlying transitions will be key elements in using models to improve land management. In many cases this is difficult to do, however, because we often do not fully understand the causes of observed vegetation changes, particularly their interactions.

A conceptual approach to deal with this is to postulate that there is usually a dominant proximate variable or a characteristic pattern of correlation among several variables that regulates particular transitions on ecological sites. In the southwestern U.S., the duration and timing of available 
soil water may be a key variable involved in many kinds of transitions (Whitford et al. 1995, Devine et al. 1998, Breshears and Barnes 1999; Table 1) and also relates closely to nutrient availability (Stafford Smith and Morton 1990, Reynolds et al. 1999, Dodd et al. 2000). Transitions may be due to threshold (non-linear) changes in the availability of soil water over time due to shifts in runoff patterns (e.g., percolation thresholds; Davenport et al. 1998) or to threshold responses of species performance to gradual changes in the soil water (e.g., species-specific soil moisture limitations). Thus, nonlinear responses may be caused by both positive feedbacks that create threshold changes in variables as well as through species tolerance limits (e.g., Austin 1985).

To anticipate transitions, we need to know something about the changes in proximate variables underlying threshold responses in vegetation and soils. Despite a wealth of information, these issues have seldom been directly addressed in New Mexico, or elsewhere. For example, is the persistent reduction of black grama abundance due to a reduction in soil moisture availability, reductions in the abundance of mycorrhizal fungi, a change in rodent herbivory levels, some other unconsidered factor, or a combination of factors? If soil moisture changes are important for black grama germination, survival, or reproduction, then, across what values of moisture availability do threshold responses occur? Are threshold or continuous changes in these variables observed in nature and what are the causes of this variation? Are threshold responses of particular species determined by the same environmental variables in all instances? Addressing these questions for key grass and shrub species will greatly improve our capacity to provide flexible, predictive models of transitions with management utility that link retrospective data and observations with comparative studies and experiments.

But what is a manager to do with stateand-transition models while we gather and synthesize these critical data? Even when mechanisms are fully understood, proximate variables such as soil moisture or mycorrhizal populations are going to be difficult to monitor directly or may change only after a transition. A promising approach is to measure factors related to key proximate variables that indicate the operation of processes that can be altered to prevent (or facilitate) a transition (Herrick 2000, Ludwig et al. 2000, Kuehl et al. 2001). For example, the presence, expansion, and spatial arrangement of bare

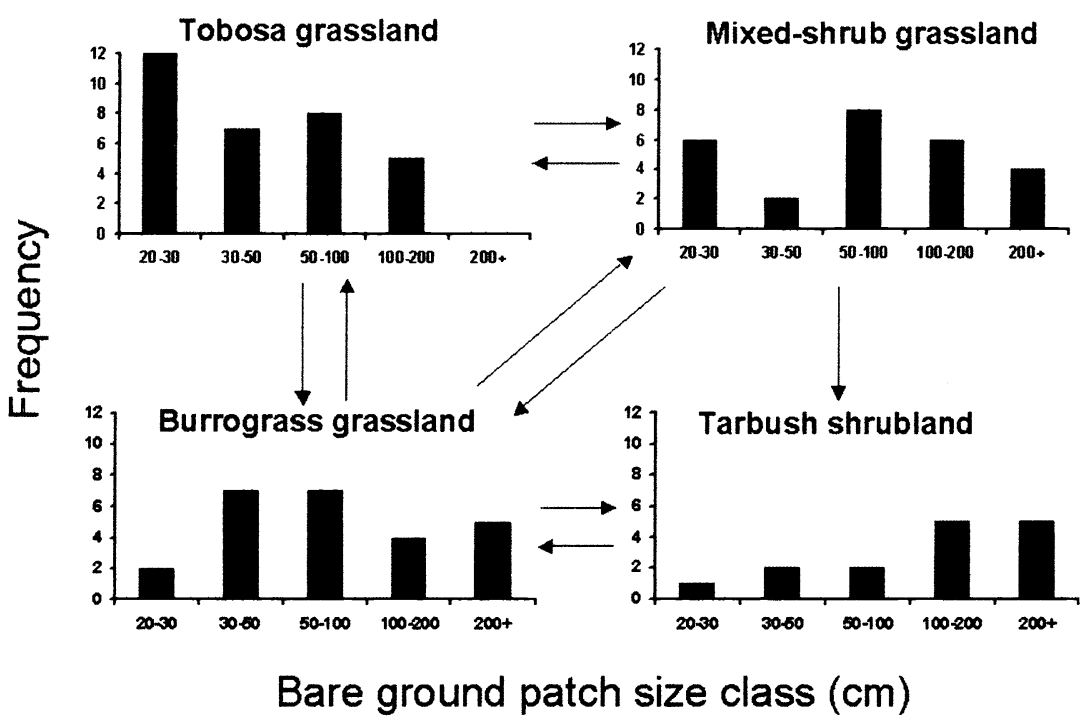

Fig. 6. Histograms for gap-intercept data (see Herrick et al. 2001) representing different states within the loamy ecological site in the SD-2 land resource unit of southern New Mexico. Graphs are arranged to parallel the state-and-transition model. Gap (bare-patch) sizes were measured along a 50-m tape. Gaps were the distance between perennial plant bases (where stems emerge from the ground) that were intercepted by the edge of the tape. Only gaps greater than $20 \mathrm{~cm}$ were tallied. Data were gathered on representative sites on the Jornada Experimental Range.

ground patches or shrubs, reduction in soil stability, or the formation of rills, litter dams, and terracettes indicate erosion that reduces soil fertility and microbial populations, water infiltration, and may eventually truncate entire soil horizons (Unpublished data, Herrick et al.). Thus, a trend towards a transition involving one or several interacting mechanisms may be revealed by indicators, even when the precise mechanisms (and critical values) are not well known.

By linking specific indicators to stateand-transition models, model developers can provide tools to help land managers determine the state that land is in and to evaluate the probability of a transition. Different qualitative indicators (Pellant et al. 2000) relate to different processes, and models can point to specific indicators that signal an approach to a particular transition. Models can include ranges in values for quantitative indicators such as perennial plant cover, shrub density, bare ground patch size, frequency, and spatial arrangement, soil compaction, and soil surface stability to define the range of structure and function characterized by states and that provide benchmarks for measurements of the processes leading to transitions. In particular, indicators such as basal and canopy gap size (Unpublished data, Herrick et al.; see Fig. 6) are correlated with other indicators of soil quality and erosion and can easily complement the plant composition data gathered by management personnel to identify states. Together, the suite of qualitative and quantitative measurements can do for state-and-transition models what the similarity index does for succession-retrogression models: they provide a means to connect field observations with theoretical expectations and management responses.

It is important to recognize that transitions usually do not happen simultaneously across entire landscapes, grazing allotments, or even pastures. In many cases, transitions occur 1 patch at a time, occurring first on areas within ecological sites that are most sensitive to change due to slight variations in soils or landscape position (Fig. 7). Over time, or across space, these patches may coalesce to produce landscape-scale phenomena (Gosz 1993). Furthermore, changes in ecosystem functioning in 1 patch may affect adjacent patches. In many arid systems, nutrients lost from patches that have undergone transitions may be redistributed to adjacent patches, increasing local production and grass cover in those patches (Ludwig and Tongway 1995). These patch-scale dynamics indicate that 1) monitoring changes in the frequency, size, or spatial arrangement of patch-scale transitions may be used to indicate the consequences of management activities, 2) monitoring transects located in "nutrient sinks" or 


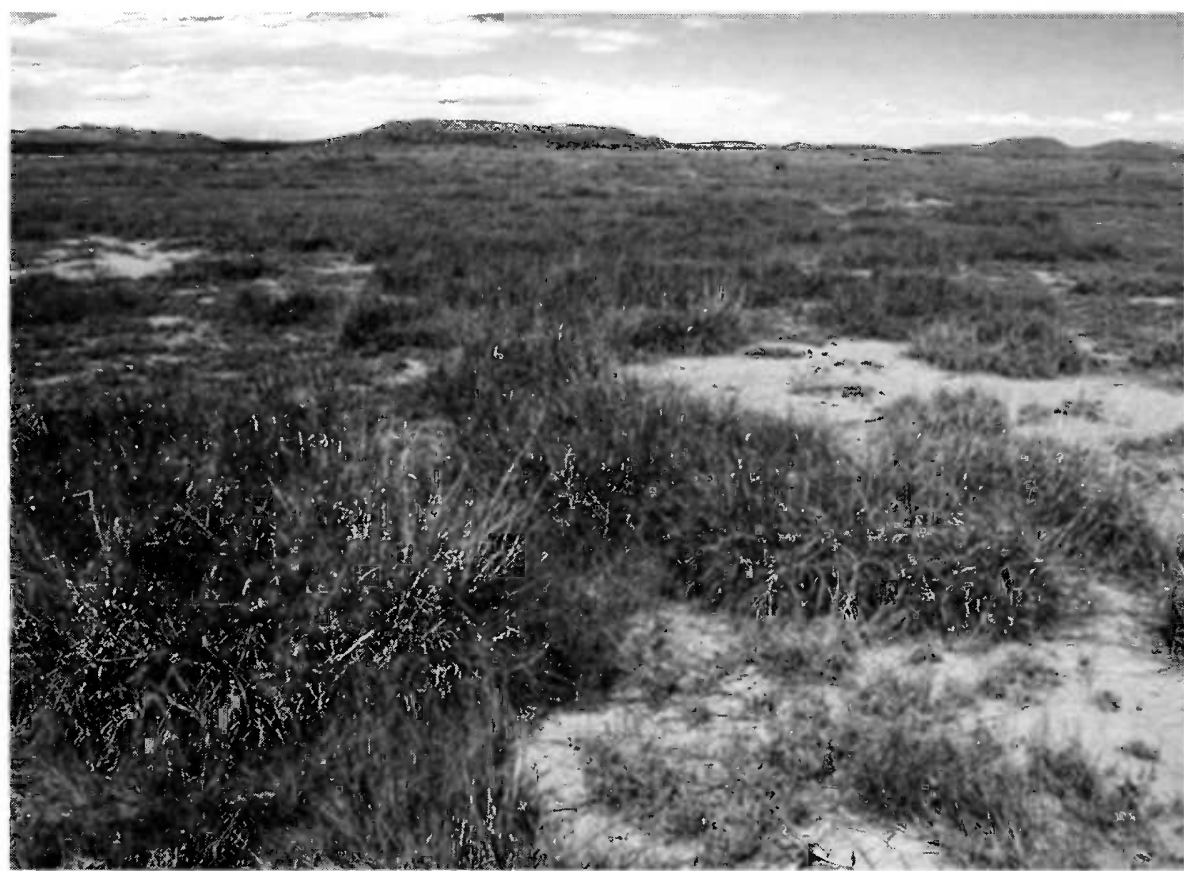

Fig. 7. An area within the clayey ecological site on the Sevilleta National Wildlife Refuge north of Socorro, N.M. in the SD-1 land resource unit. Grasses in the foreground include galleta (Pleuraphis jamesii Torr.), alkali sacaton, and burrograss. This refuge has been excluded from livestock grazing since 1973. Despite rest, some large bare patches remain. These patches tend to have low soil aggregate stability indicating reduced capacity for infiltration. This suggests that a transition has occurred, albeit at a small scale.

insensitive locations will be incapable of providing early warning of a broad-scale transition, and 3) it is necessary to interpret fine-scale indicators within patches (e.g. Pellant et al. 2000) by considering patterns across entire landscapes.

\section{Implications of state-and-transition models for management}

As agencies and individuals adopt the state-and-transition model framework, and specific models are produced, it is important to consider how these concepts can change on-the-ground management and how the models will be used. First, the state-and-transition model implies that, for all practical purposes, some areas are incapable of being restored to a historic state by intensive accelerating practices. What constitutes "for all practical purposes" depends on the processes maintaining an undesirable state and the costs of reversing them. If a transition is determined by the lack of propagules of a dominant species at a site, it may be relatively inexpensive to reverse it. On the other hand, if the transition is caused by soil degradation, then the cost of reversing it would be far greater.

By assigning land to a state, we assert the existence of particular processes and constraints in that land that indicate man- can convey what has happened on different soils, and what will happen given the operation of the processes embodied in a model. Managers can use case-specific information, supplemented with indicators in many instances, to evaluate the likelihood that particular processes are operating, evaluate management options with respect to those processes, and make a determination of the costs and benefits of those options. The refinement of transition-specific indicators and reporting of reference values with specific models will aid this process.

In using reference indicator values, it is ill-advised to consider maximizing grazing returns by pushing a rangeland as close as possible to a point of transition without "crossing" into another state. It is clear that temporally unpredictable and uncontrollable factors (e.g., climate) and a high degree of spatial variability in site properties (e.g., amounts of run-on, variation in soil gravel content) interact with factors under management control to cause rapid changes in key, proximate variables in space and time. Thus, it is doubtful that indicator values for specific transitions will be precise (Hobbs and Morton 1999, Muradian 2001). Management with respect to state-and-transition models calls for conservative strategies aimed at detecting and reversing trajectories toward variable environmental thresholds. This is the essence of "adaptive management" in the state-and-transition model context.

\section{Conclusions and recommendations}

State-and-transition models organize the combined understanding of scientists and managers to explain ecosystem dynamics across variable rangeland landscapes. It is important to recognize that this framework is not a blanket replacement of an outdated succession-retrogression model, but a complement to it that accounts for the existence of multiple equilibria, as well as the return to equilibrium following perturbations. Furthermore, the contrast between communities and states can be used to distinguish the need for facilitating and accelerating management practices. The results of a broad range of studies and personal experiences can be summarized within this framework and the resulting views can be continually updated as new observations and ideas emerge (Bradshaw and Borchers 2000)

In order for the understanding represented in state-and-transition models to be communicated, refined, and compared against the field observations of managers, we suggest the inclusion of several com- 
ponents in individual models. First, the catalog of states proposed by Westoby et al. (1989) can contain information that can be used to place land in ecosystem states and, consequently, provide benchmarks for assessing the risk of a transition. Ranges for quantitative indicator values, including line-intercept data of cover and species composition, belt transect data for invasive or encroaching species, gap intercept data (Fig. 6), and soil aggregate stability index values (Herrick et al. 2001) relate closely to many of the processes defining states in the New Mexico models that we have produced and form the core of the standard set of measurements we are currently gathering. The reference areas in which these data are gathered, (or estimates of reference values where such areas no longer exist) are selected by range professionals and scientists that contribute to model development. Second, the catalog of transitions can include a list of key qualitative and quantitative indicators, and descriptions of changes that occur in them, that suggest progress towards a transition. Finally, the hypotheses, assertions, literature and observations justifying the structure of each model should be documented. This allows the mechanistic foundations of models to be evaluated and challenged by the science and management communities so that model structures can evolve.

Collaborations between the management agencies and the research community will continue to play a large role in improving the utility of the state-and-transition model approach and several specific directions are indicated in this review. First, ecological sites and land resource unit delineations should be refined to better reflect key differences in soil, topographic, and climatic properties that create differences in vegetation dynamics. Multivariate analyses of broad-scale soils, vegetation, geomorphological (Gile and Grossman 1997, McAuliffe 1994), and climatic (Comrie and Glenn 1998) datasets can be extremely useful in the effort. Second, efforts must be continued to gather longterm data (in an experimental context where possible), stratified by soil series, and at appropriate spatial scales. Few experimental studies have directly addressed the constraints to plant dynamics on different soils (e.g., Northrup et al. 1999, Vandekerckhove et al. 2000), despite clear evidence that these constraints vary among sites. Studies of the mechanisms producing transitions are needed to interpret long-term vegetation data and develop suitable indicators.
Third, both academic ecologists and resource managers should attempt to link information on other components of rangelands valued by land owners and society (e.g., biodiversity ) to state-andtransition models so that their responses can be interpreted alongside those of plants and soils. (e.g., Van der Haegan et al. 2000, Bestelmeyer and Wiens 2001).

Our efforts in New Mexico lead us to conclude that a great deal of information has yet to be gathered, but that a great deal of understanding already exists that had not yet been captured in a useful form. The models we produced have been wellreceived by many field managers, for both complementing and organizing their knowledge as well as highlighting uncertainties. Models can improve the capacity of managers to evaluate the costs and consequences of management decisions and rally researchers around unanswered questions. For this reason alone, the production of state-and-transition models is a worthwhile endeavor. As models become firmly linked to a mechanistic understanding of plant pattern, dynamics and indicators of the processes underlying them, the models will become invaluable.

\section{Literature cited}

Allen-Diaz, B. and J. W. Bartolome 1998. Sagebrush-grass vegetation dynamics: comparing classical and state-transition models. Ecol. Appl. 8:795-804.

Archer, S. 1989. Have southern Texas savannas been converted to woodlands in recent history? Amer. Natur. 134:545-561.

Archer, S., C. Scifres, C.R. Bassham, and R. Maggio. 1988. Autogenic succession in a subtropical savanna: conversion of grassland to thorn woodland. Ecol. Monogr. 52:111-127.

Ash, A. J., J. A. Bellamy, and T. G. H. Stockwell. 1994. State and transition models for rangelands. 4. Application of state and transition models in northern Australia. Trop. Grassl. 28:223-228.

Austin, M. P. 1985. Continuum concept, ordination methods, and niche theory. Annu. Rev. Ecol. Syst. 16:39-61.

Bellamy, J. A. and J. R. Brown. 1994. State and transition models for rangelands. 7 . Building a state and transition model for management and research on rangelands. Tropical Grassl. 28:247-255.

Belsky, A. J. 1996. Viewpoint: Western juniper expansion: Is it a threat to arid northwestern ecosystems? J. Range Manage. 49:53-59.

Bestelmeyer, B. T. and J. A. Wiens. 2001. Ant biodiversity in semiarid landscape mosaics: the consequences of grazing vs. natural heterogeneity. Ecol. Appl. 11:1123-1140.
Bradshaw, G. A. and J. G. Borchers. 2000. Uncertainty as information: narrowing the science-policy gap. Conserv. Ecol. 4: 7. [online] URL:

http://www.consecol.org/vol4/iss 1/art7, 15 May 2002

Breshears, D. D. and F. J. Barnes. 1999. Interrelationships between plant functional types and soil moisture heterogeneity for semiarid landscapes within the grassland/forest continuum: a unified conceptual model. Landscape Ecol. 14:465-478.

Brown, J. H., T. J. Valone, and C. G. Curtin. 1997. Reorganization of an arid ecosystem in response to recent climate change. Proc. Nat. Acad. Sci. USA 94:9729-9733.

Brown, J. R. 1994. State and transition models for rangelands. 2. Ecology as a basis for rangeland management: performance criteria for testing models. Trop. Grassl. 28:206-213.

Brown, J. R. and S. Archer. 1987. Woody plant seed dispersal and gap formation in a North American subtropical savanna woodland: the role of domestic herbivores. Vegetatio 73:73-80.

Brown, J. R. and S. Archer. 1999. Shrub invasion of grassland: recruitment is continuous and not regulated by herbaceous biomass or density. Ecol. 80:2385-2396.

Bulloch, H. E. and R. E. Neher. 1980. Soil Survey of Dona Ana County Area, New Mexico. USDA Soil Conservation Service, Washington, D.C.

Bureau of Land Management. 2001. H-41801- Rangeland Health Standards, BLM Manual, Release 4-107, Bureau of Land Management, Washington, D.C.

Campbell, R. S. 1929. Vegetative succession in the Prosopis sand dunes of southern New Mexico. Ecol. 10:392-398.

Callaway, R. M. and F. W. Davis. 1993. Vegetation dynamics, fire, and the physical environment in coastal central California. Ecol. 74 1567-1578.

Clements, F. E. 1916. Plant succession: an analysis of the development of vegetation. Carnegie Inst., Washington Pub. 242:1-512.

Comrie, A. C. and E. C. Glenn. 1998. Principal components-based regionalization of precipitation regimes across the southwest United States and northern Mexico, with an application to monsoon precipitation variability. Climate Res. 10:201-215.

Creque, J. A., S. D. Bassett, and N. E. West. 1999. Viewpoint: Delineating ecological sites. J. Range Manage. 52:546-549.

Davenport, D. W., D. D. Breshears, B. P. Wilcox, and C. D. Allen. 1998. Viewpoint: Sustainability of piñon-juniper ecosystemsa unifying perspective of soil erosion thresholds. J. Range Manage. 51:231-240.

Devine, D. D., M. K. Wood, and G. B. Donart. 1998. Runoff and erosion from a mosaic tobosagrass and burrograss community in the northern Chihuahuan Desert grassland. J. Arid Environ. 39:11-19.

Dodd M. B., W. K. Lauenroth, and I. C. Burke 2000. Nitrogen availability through a coarse-textured soil profile in the shortgrass steppe. Soil Sci. Soc. Amer. J. 64:391-398. 
Dyksterhuis, E. J. 1949. Condition and management of rangeland based on quantitative ecology. J. Range Manage. 2:104-115.

Friedel, M. H. 1991. Range condition assessment and the concept of thresholds: a viewpoint. J. Range Manage. 44:422-426.

Freidel, M. H. 1997. Discontinuous change in arid woodland and grassland vegetation along gradients of cattle grazing in central Australia. J. Arid Environ. 37:145-164.

Friedel, M. H., G. Pickup, and D. J. Nelson. 1993. The interpretation of vegetation change in a spatially and temporally diverse arid Australian landscape. J. Arid Environ. 24:241-260.

Fuhlendorf, S. D., D. D. Briske, and F. E. Smeins. 2001. Herbaceous vegetation change in variable rangeland environments: The relative contributions of grazing and climatic variability. Appl. Veg. Sci. 4:177-188.

George, M. R., J. R. Brown, and J. Clawson. 1992. Application of nonequilibrium ecology to management of Mediterranean grasslands. J. Range Manage. 45:436-440.

Gile, L. H. and R. B. Grossman. 1997. The Desert Project Soil Monograph. Natural Resources Conservation Service, USDA Nat. Soil Surv. Center, Lincoln, Neb.

Gosz, J. R. 1993. Ecotone hierarchies. Ecol. Appl. 3:369-376.

Grossman, D. H., D. Faber-Langendoen, A.S. Weakley, M. Anderson, P. Bourgeron, R. Crawford, K. Goodin, S. Landaal, K. Metzler, K. Patterson, M. Pyne, M. Reid, and L. Sneddon. 1998. Terrestrial Vegetation of the United States. Volume 1: The National Vegetation Classification System:Development, Status, and Applications. The Nature Conservancy, Arlington, Virg.

Hennessy, J. T, R. P. Gibbens, J. M. Tromble, and M. Cardenas. 1983. Vegetation changes from 1935-1980 in mesquite dunelands and former grasslands of southern New Mexico. J. Range Manage. 36:370-374.

Herbel, C. H. and R. P. Gibbens. 1989. Matric potential of clay loam soils on arid rangelands in southern New Mexico. J. Range Manage. 42:386-392.

Herbel, C. H., F. N. Ares, and R. H. Wright. 1972. Drought effects on a semidesert grassland range. Ecol. 53:1084-1093.

Herrick, J. E. 2000. Soil quality: an indicator of sustainable land management? Appl. Soil Ecol. 15:75-83

Herrick, J. E., J. R. Brown, A. Tugel, P. L. Shaver, and K. M. Havstad. 2002. Application of soil quality to monitoring and management: Paradigms from rangeland ecology. Agro. J. 94:3-11.

Herrick J. E., W. G. Whitford, A. G. de Soyza, J. W. Van Zee, K. M. Havstad, C. A. Seybold, and M. Walton. 2001. Field soil aggregate stability kit for soil quality and rangeland health evaluations. Catena $44: 27-35$
Hobbs R. J. and S. R. Morton. 1999. Moving from descriptive to predictive ecology. Agrof. Systems 45:43-55.

Kingsland, S. E. 1985. Modeling Nature: Episodes in the History of Population Ecology. Univ. of Chicago Press, Chicago, Ill

Kuehl, R. O., M. P. McClaran, and J. Van Zee. 2001. Detecting fragmentation of cover with line intercept measures in simulations of Desert Grassland conditions. J. Range Manage. 54:61-66.

Laycock, W. A. 1991. Stable states and thresholds of range condition on North American rangelands: a viewpoint. J. Range Manage. 44:427-433.

Ludwig, J. A. and D. J. Tongway. 1995. Spatial organization of landscapes and its function in semiarid woodlands, Australia. Landscape Ecol. 10:51-63.

Ludwig, J. A., D. J. Tongway, and S. G. Marsden. 1994. A flow-filter model for simulating the conservation of limited resources in spatially heterogeneous, semi-arid landscapes. Pacific Conservation Biol. 1:209-213.

Ludwig J. A., G. N. Bastin, R. W. Eager, R. Karfs, P. Ketner, and G. Pearce. 2000. Monitoring Australian rangeland sites using landscape function indicators and groundand remote-based techniques. Environ. Mon. and Assess. 64:167-178.

McAuliffe, J. R. 1994. Landscape evolution, soil formation, and ecological patterns and processes in Sonoran desert bajadas. Ecol. Monogr. 64:111-148.

McClaran, M. P, D. L. Angell, and C. Wissler. In press. Santa Rita Experimental Range Digital Database: User's Guide. USDA Forest Serv. Rocky Mountain Res. Sta., Gen. Tech. Rept., RMRS-GTR-XXX.

McPherson, G. R. 1995. The role of fire in desert grasslands. p 130-151 In: $\mathrm{M}$. McClaran and T. R. Van Devender (eds) The desert grassland. Univ. of Arizona Press, Tucson, Ariz.

Miller, M. E. 1999. Use of historic aerial photography to study vegetation change in the Negrito Creek watershed, southwestern Mew Mexico. The Southwestern Natur. 44:121-137.

Muller, C. H. 1940. Plant succession in the Larrea-Flourensia climax. Ecol. 21 206-212.

Muradian, R. 2001. Ecological thresholds: a survey. Ecol. Econ. 38:7-24.

Neilson, R. P. 1986. High resolution climatic analysis and southwest biogeography. Sci. 232:27-34

Northrup, B. K., J. R. Brown, and J. A. Holt. 1999. Grazing impacts on the spatial distribution of soil microbial biomass around tussock grasses in a tropical grassland. Appl. Soil Ecol. 399:1-12.

Pellant, M., P. Shaver, D. Pyke, and J. Herrick. 2000. Interpreting indicators of rangeland health, version 3 . Tech. Reference 1734-6. U. S. Department of the Interior, Bureau of Land Management, National Science and Technology Center Information and Communications Group, Denver, Colo.
Plant, R. E., M. P. Vayssieres, S. E. Greco, M. R. George, and T. E. Adams. 1999. A qualitative spatial model or hardwood rangeland state-and-transition dynamics. J. Range Manage. 52:51-59.

Rango, A., S. Goslee, J. Herrick, M. Chopping, K. Havstad, L. Huenneke, R. Gibbens, R. Beck, and R. McNeely. (In press). Remote sensing documentation of historic rangeland remediation treatments in southern New Mexico. J. Arid Environ.

Reitkerk, M. and J. van de Koppel. 1997. Alternate stable states and threshold effects in semiarid grazing systems. Oikos 79:69-76.

Reynolds, J. F., R. A. Virginia, P. R. Kemp, A. G. De Soyza, and D. C. Tremmel. 1999. Impact of drought on desert shrubs: effects of seasonality and degree of resource islands development. Ecol. Monogr. 69:69-106.

Rodriguez Iglesias, R. M. and M. M. Kothman. 1997. Structure and causes of vegetation change in state and transition model applications. J. Range Manage. 50: 399-408.

Scheffer, M., S. Carpenter, J. A. Foley, C. Folke, and B. Walker. 2001. Catastrophic shifts in ecosystems. Nature 413:591-596.

Schlesinger, W. H., J. F. Reynolds, G. L. Cunningham, L. F. Huenneke, W. M. Jarrell, R. A. Virginia, and W. G. Whitford. 1990. Biological feedbacks in global desertification. Sci. 247:1043-1048.

Shiflet, T. N. 1975. Range sites and soils in the United States. p. 26-33 In: D. N. Hyder (ed.) Arid Shrublands: Proceedings of the Third Workshop of the U.S./Australia Rangeland Panel. Soc. for Range Manage., Denver, Colo.

Society for Range Management, Task Group on Unity in Concepts and Terminology. 1995. New concepts for assessment of rangeland condition. J. Range Manage 48:271-282.

Stafford Smith, D. M. and S. R. Morton. 1990. A framework for the ecology of arid Australia. J. Arid Environ. 18:255-278.

Stringham, T. K., W. C. Krueger, and P. L. Shaver. 2001. States, transitions, and thresholds: Further refinements for rangeland applications. Oregon State Univ. Agr. Exp. Sta., Special Rep. 1024.

Strittholt, J. R. and R. E. J. Boerner. 1995. Applying biodiversity GAP analysis in a regional nature-reserve design for the edge of Appalachia, Ohio (USA). Conserv. Biol. 9: 1492-1505.

Svejcar, T. and J. R. Brown. 1991. Failures in the assumptions of the condition and trend model for managing natural ecosystems. Rangelands 13:165-167.

Tansley, A. J. 1935. The use and abuse of vegetational concepts and terms. Ecol. 16:284-307.

USDA Natural Resources Conservation Service. 1997. National Range and Pasture Handbook. U.S. Dep. Agr., Washington, DC.

USFS. 2000. National Forest System Land Resource Management Planning; Final Rule. Federal Register 65 (219.20): 67574-67575. 
Van Auken, O. W. and J. K. Bush. 1997. Growth of Prosopis glandulosa in response to changes in aboveground and belowground interference. Ecol. 78:1222-1229.

Van der Haegen W. M, F. C. Dobler, and D. J. Pierce. 2000. Shrubsteppe bird response to habitat and landscape variables in eastern Washington, USA. Conserv. Biol. 14:1145-1160

Vandekerckhove, L., J. Poesen , D. O. Wijdenes, J. Nachtergaele, C. Kosmas, $M$. J. Roxo, and T. deFigueiredo. 2000. Thresholds for gully initiation and sedimentation in Mediterranean Europe. Earth Surface Processes and Landforms 25:1201-1220.

Weltzin J. F., S. Archer, and R. K. Heitschmidt. 1997. Small-mammal regulation of vegetation structure in a temperate Savanna. Ecol. 78:751-763.
Westman, W. E. 1978. Measuring the inertia and resilience of ecosystems. Biosci. 28:705-710.

Westoby, M. 1980. Elements of a theory of vegetation dynamics in arid rangelands. Israel J. Bot. 28:169-194.

Westoby, M, B. Walker, and I. Noy-Meir. 1989. Opportunistic management for rangelands not at equilibrium. J. Range Manage. 42:266-274

Wiegand, T. and S. G. Milton. 1996 Vegetation change in semiarid communities: Simulating probabilities and time scales. Vegetatio 125:169-183.

Wiens, J. A. 1984. On understanding a nonequilibrium world: Myth and reality in community patterns and processes, p. 439-457 In: D. R. Strong, D. Simberloff, L. G. Abele, and A. B. Thistle (eds). Ecological Communities: Conceptual Issues and Evidence Princeton Univ. Press, Princeton, N.J.
Whisenant, S. G. 1999. Repairing damaged wildlands: a process-orientated, landscapescale approach. Cambridge Univ. Press, Cambridge, U.K.

Whitford, W. G., G. Martinez-Turanzas, and E. Martinez-Meza. 1995. Persistence of desertified ecosystems: explanations and implications. Environ, Monitoring and Assess, 37:319-332.

Wondzell, S. M., G. L. Cunningham, and D. Bachelet. 1996. Relationships between landforms, geomorphic processes, and plant communities on a watershed in the northern Chihuahuan desert. Landscape Ecol. 11:351-362.

Wright, H. A., S. C. Bunting, and L. F. Neuenschwander. 1976. Effect of fire on honey mesquite. J. Range Manage. 29:467-471.

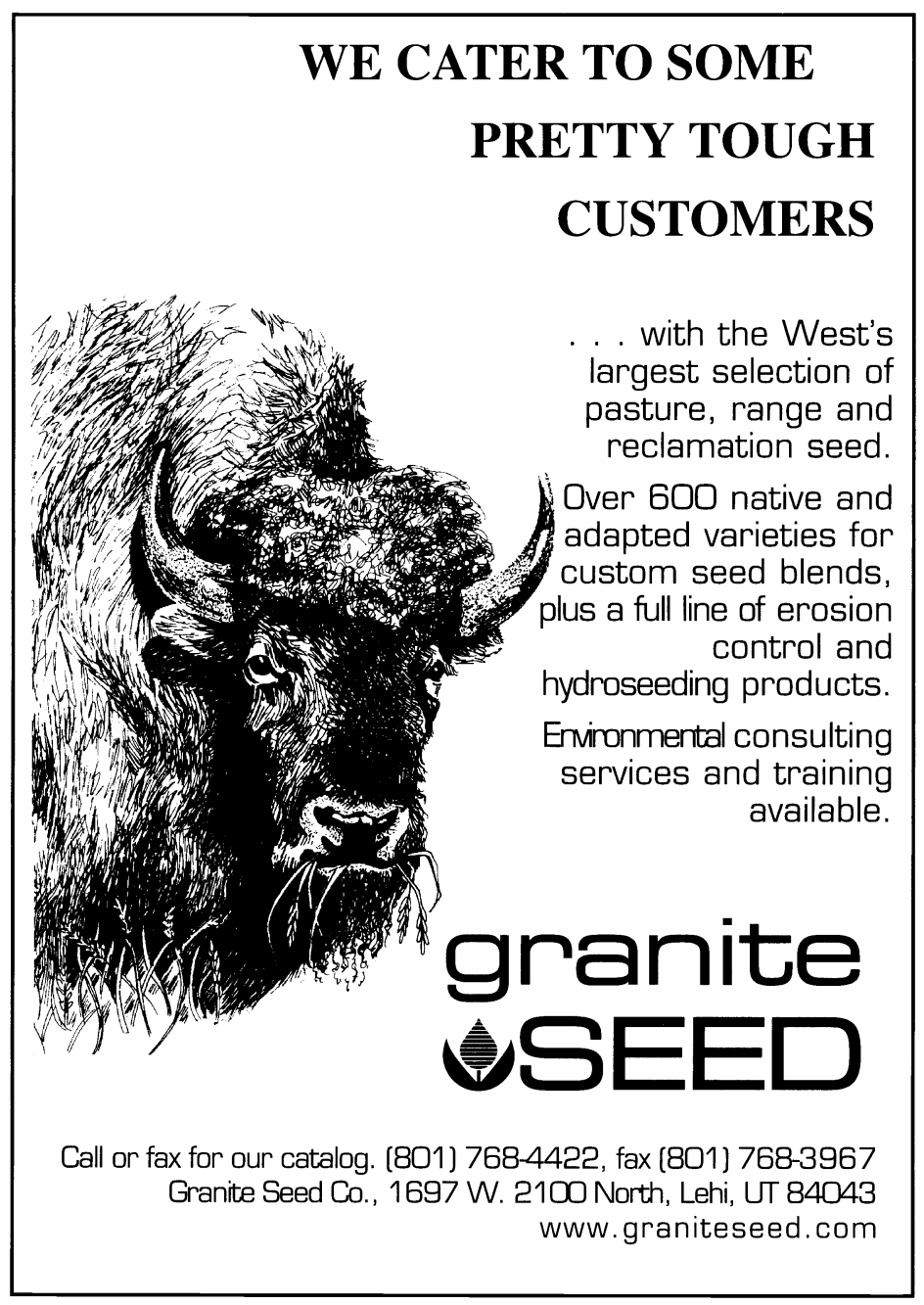

